\title{
Ilgaz Ormanlarında Saf Uludağ Göknarı ve Saf Uludağ Göknarı- Sarıçam Meşcerelerinde Bazı Toprak Özelliklerinin Uzaysal Değişkenliği
}

\author{
Fatih GÜREL ${ }^{1 *}$, Sabit ERŞAHİN ${ }^{2}$ \\ ${ }^{1}$ Kastamonu İl Tarım ve Orman Müdürlüğü, 37100, KASTAMONU \\ ${ }^{2}$ Çankırı Karatekin Üniversitesi, Orman Fakültesi, Orman Mühendisliği Bölümü, Toprak İlmi ve Ekoloji Anabilim \\ Dalı, 18200, ÇANKIRI
}

\section{Öz}

Toprak değişkenliğinin sistematik bir yapı göstermesi halinde jeoistatistiksel yöntemlerle analiz edilmesi klasik istatistiksel yöntemlere göre önemli avantajlar sağlamaktadır. Bu çalışmada Ilgaz Dağı doğal orman alanlarında birebirine bitişik saf Uludağ Göknarı (Abies nordmanniana subsp. Bormülleriana) ve Sarıçam (Pinus sylvestris ) Saf Uludağ Göknarı karışımı iki meşcerede 0-15 ve 15-30 cm toprak derinliklerinde bazı toprak özelliklerinin uzaysal değişkenliğinin karşılaştırılması amaçlanmıştır. Toprak özelliklerinin deneysel semivaryogramları modellendikten sonra, bayağı (ordinary) krigleme yöntemi ile yüzey haritaları oluşturulmuştur. Karışık meşcerede üssel modelin saf meşcerede ise küresel modelin genellikle toprak özelliklerinin uzaysal yapısını daha iyi tanımladığı belirlenmiştir. Nugget etkisi \%0,03 ve \%100 arasında değişen değerler almış olup, genelde her iki meşcerede de yüksek olması, toprakların kısa mesafelerde oldukça değişken olduğunu göstermektedir. Jeoistatistiksel range (Ao) 4,38 ve 167,03 m arasında değişen değerler almıştır. Ancak, Ao değerleri bakımından meşcere tipi ve toprak derinlikleri arasında sistematik bir farklılık bulanamamıştır. Her iki meşcerede de toprak özelliklerinin uzaysal bağımlılığı 0-15 cm derinlikte daha düşük bulunmuştur. Toprak özelliklerinin kısa mesafelerde aşırı değişken olması nedeniyle krigleme entepolasyonundan başarılı sonuçlar alınamamıştır. İleride yapılacak benzer çalışmalarda bu hususun özellikle dikkate alınarak örnekleme aralıklarının daha kısa tutulması önerilmektedir.

Anahtar Kelimeler: Bayağı krigleme, küresel model, nugget etkisi, semivaryogram, üssel model.

\section{Spatial variation of some soil properties on pure Abies and Abies- Pinus sys/vetsris stands in Ilgaz Mountain forests}

\begin{abstract}
Use of geostatistical methods to analyze soil variation when systematic variability is the case provides great advantages over classical statistical techniques. In this study, spatial variability of some soil properties were compared in 0-15 and 15-30 cm depth of soils on a pure stand of Abies (Abies nordmanniana subsp. Bormülleriana) and on a mixed stand of Abies and Pinus sylvestris. Experimental semivariograms for soil properties were modelled and surface maps were built by ordinary kriging technique. In general, exponential model described the experimental semivariograms for soil attributes most properly on the mixed stand and spherical model on the pure stand. Nugget effect ranged from $0.03 \%$ to $100 \%$ and generally high in both of the stands, indicating high short-range variability of soil attributes. Geostatistical range was between $4.30 \mathrm{~m}$ and $167.03 \mathrm{~m}$ and no consistent differences occurred in Ao neither between stands nor soil depths. Spatial dependency was greater in 0-15 cm depth in both of the stands. Performance of kriging interpolations was generally poor due to high short-range variation of soil properties, and this should be considered in determination of sampling intervals in similar prospective studies.
\end{abstract}

Keywords: Ordinary kriging, exponential model, nugget effect, semivariogram, spherical model. 


\section{Giriş}

Topraklar, ana materyal, iklim, topografya ve canlılar arasındaki etkileşimin bir sonucu olarak oluşmuşlardır. Farklı koşullarda, her bir faktörün toprak özelliklerinin şekillenmesindeki etkisi farklı olduğundan, toprak özellikleri uzaysal ve zamansal olarak değişkenlik göstermektedir. Dikey yönde toprak değişkenliğinin başlica nedeni toprak oluşumunun bir sonucu olarak ortaya çıkan toprak horizonlarıdır. Topraklar, bu horizonların organik madde içeriği, hacim ağırlığı, renk, tekstür, strüktür, baz doygunluğu, toprak reaksiyonu (pH) ve elektriksel iletkenlik (EC) gibi fiziksel ve kimyasal özellikler bakımından farklılık göstermesine bağlı olarak dikey yönde değişkenlik göstermektedirler (Trangmar et al., 1985).

Topraklar arazide yatay yönde gelişigüzel (random) veya sistematik olmak üzere iki şekilde değişkenlik gösterebilirler. Toprak özelliklerinin arazide mesafeye bağlı olarak kendine benzemesi, yani mesafe ile otokorele olması, sistematik değişkenlik olarak adlandırılır. Random değişkenlik göstermesi halinde, toprak özelliklerinin değişkenliği klasik istatistiksel yöntemler kullanılarak analiz edilebilir. Ancak, toprak özelliklerinin sistematik değişkenlik göstermesi halinde klasik istatistiksel yöntemler başarısız kalır ve bu durumda jeoistatistiksel yöntemlerin kullanılması tavsiye edilmektedir (Nielsen et al., 1973; Journel and Huijbregts, 1978; Trangmar et al., 1985; Warrick and; Webster and Oliver, 2001). Çok sayıda araştırmacı toprak özelliklerinin sistematik uzaysal değişkenlik sergilemesi nedeniyle, bu topraklara ilişkin uzaysal bağımlılı̆̆ın analizinde jeoistatistiksel yöntemlerin kullanılmasının oldukça faydalı sonuçlar verdiğini rapor etmişlerdir. Jeoistatistiğin bir diğer önemli avantajı ise, ilgili değişkenin uzaysal yapısına ilişkin parametrelerin örnekleme yapılan noktalardaki değerleri ile kullanarak, örnekleme yapılamayan noktalardaki değerlerinin tahminine olanak sağlamasıdır (Webster and Oliver, 2007; Webster, 2008).

Jeoistatistik, tanımsal istatistiksel analiz, uzaysal modelleme ve uzaysal enterpolasyon olmak üzere üç aşamada tamamlanır (Isaaks and Srivastava, 1989). İlk aşamada ilgili özelliğin dağılımı incelenir. İkinci aşamada uzaysal yapı modellenir ve üçüncü aşamada ise eğer uzaysal yapı uygunsa krigleme enterpolasyonu ile ilgili değişkenin yüzey haritası oluşturulur (Çetin ve Tütüncü, 1998; Mulla and McBratney, 2000).

Orman topraklarının uzaysal değişkenliğinin jeoistatistiksel yöntemlerle analizi üzerine diğer ülkelerde çok sayıda araştırma yapılmıştır (Ovalles and Collins, 1988; Geypens et al., 1999; Camberdella and Karlen, 1999; Castrignano et al., 2000; Needelman et al., 2001; Wu et al., 2002; Payn et al., 1999; Gallardo, 2003; Sun et al., 2003; Jennifer et al., 2005; Boruvka et al., 2007; Gallardo and Parama, (2007).

Yapılan bu çalışmalarda toprakların sistematik değişkenlik gösterdikleri rapor edilmiştir. Ancak, ülkemizde orman topraklarının jeoistatistiksel yöntemlerle uzaysal değişkenliğinin analizine ilişkin çalışma sayısı oldukça sınırlıdır (Başaran, 2005; Gül, 2015). Farklı ölçek, topografya ve meşcerelerde çalışmalar yapılarak bu alanda ulusal ve uluslararası bilgi ve veri tabanına destek verilmelidir.

$\mathrm{Bu}$ çalışma ile Kastamonu iline bağlı Ilgaz dağı doğal orman alanlarındaki yaklaşık 10 hektarlık bir sahada (birbirine bitişik yaklaşık 5 ha göknar ve 5 ha göknar-sarıçam karışık meşceresinde) 0-15 ve 15-30 cm toprak derinliklerinde temel toprak özelliklerinin uzaysal değişkenliği jeoistatistiksel yöntemlerde analizi edilerek karşılaştırılmıştır. Elde edilen sonuçlar ve deneyimlerin ileride yapılacak benzer çalışmalarda özellikle örnekleme deseninin ve yoğunluğunun belirlenmesinde yol gösterici olacağı düşünülmektedir.

\section{Materyal ve Yöntem}

\subsection{Materyal}

\subsection{1 Çalışma Alanının Tanımı}

Çalışma alanı, Kastamonu iline yaklaşık $30 \mathrm{~km}$ mesafedeki Ilgaz dağında Bostan İşletme Şefliği sorumluluğuna

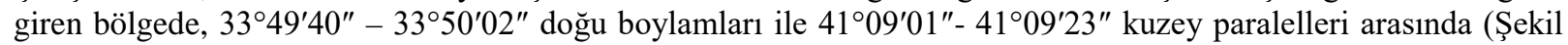
1) yer almaktadır. Çalışma alanı, Ilgaz dağının kuzeye bakan yamacında yer almakta olup, denizden yüksekliği 1284-1560 m arasında değişmektedir, arazi yapısı ise engebeli ve yer yer aşırı eğimlidir. 


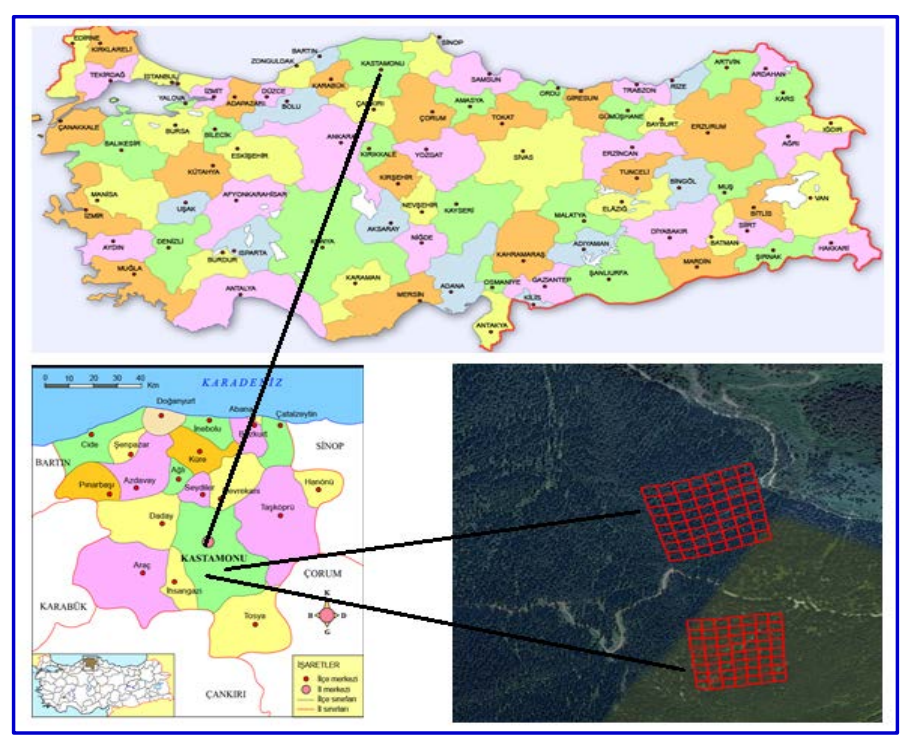

Şekil 1. Çalışma alanının konumu (üstte) ve örnekleme noktalarının çalışma alanındaki konumları (altta sağda).

\subsection{Yöntemler}

\subsubsection{Toprak örnekleme}

Çalışma alanında birbirine bitişik 5 ha göknar ve 5 ha göknar-sarıçam karışık meşceresinde eğim, bakı ve yükseklik yönünden benzer iki alan seçilmiştir (Şekil 1). Çalışma alanları 30 x $30 \mathrm{~m}$ kare ızgaralara ayrılıp, ızgaraların köşelerinde belirlenen örnekleme noktalarında $0-15 \mathrm{~cm}$ ve $15-30 \mathrm{~cm}$ derinliklerden toprak örnekleri alınmıştır. Otuz metreden daha kısa mesafelerdeki değişkenliği analiz edebilmek için (semivaryogramların kısa mesafelerdeki davranışlarının modellenebilmesi için) birbirine dik yönlerde gelişigüzel seçilen bazı ızgaraların üzerinde ara hatlar oluşturulmuştur (sık örnekleme hatları) (Şekil 2). Bu şekilde her iki meşcerede de oluşturulan 9 ar adet ara hat üzerinde başlangıç noktasından itibaren $5,15,20$ ve 25 . m'de $0-15$ ve $15-30 \mathrm{~cm}$ derinliklerden toprak örnekleri alınmıştır. Örnekleme şekli, ara hatlar da dikkate alındığında düzensiz ızgaralar (irregular grids) yöntemi olarak nitelendirilebilir.

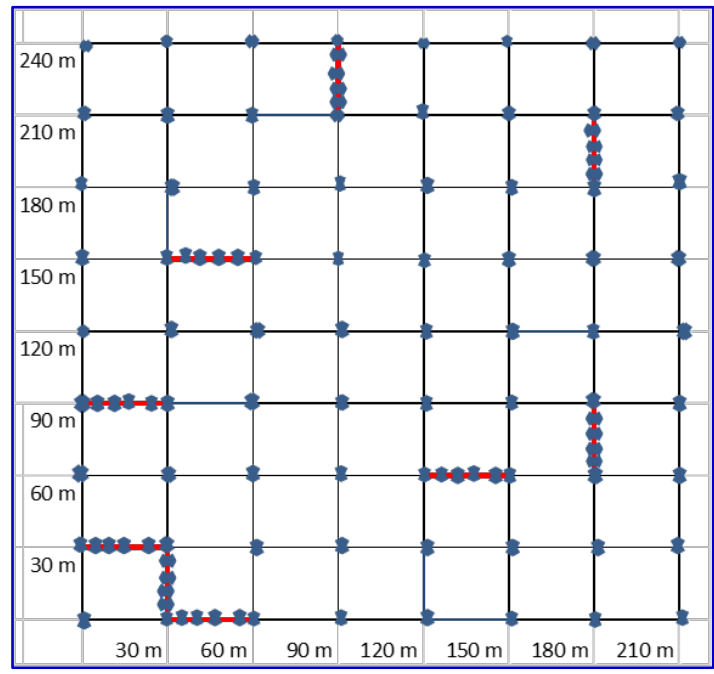

Şekil 2. Saf (sarıçam) ve karışık (göknar- sarıçam) meşcerelerinde örnekleme noktalarının çalışma alanında dağılımını gösteren örnekleme planı.

Çalışma alanında alınan toplam 428 toprak örneği laboratuvara nakledilerek hava kuru hale getirildikten sonra 2 mm'lik eleklerden elenerek analize hazır hale getirilmiştir. Daha sonra toprak örneklerinde kireç (Kacar, 1996), organik madde (Nelson and Sommers, 1982), alınabilir fosfor (Kacar ve Kovanc1, 1982), tarla kapasitesi, solma noktası ve yarayışlı su içeriği (Cassel and Nielsen, 1986), hacim ağırlığı (Blake and Hartage, 1986), toprak tekstürü (Gee and Bauder, 1986), elektriksel iletkenlik (EC) ve toprak reaksiyonu (pH) (Janzen, 1993) analizleri 
yapılmıştır. Örnekleme noktalarının koordinatları örnekleme esnasında bir Küresel Konumlama Sistemi (GPS) ile belirlenerek kaydedilmiştir.

\subsubsection{Jeoistatistiksel Modelleme}

Jeoistatistiksel analizlerde, ilk olarak toprak özelliklerinin tanımsal istatistikleri hesaplanmıştır (Isaaks and Srivastava, 1989). Webster (2001) tarafından tavsiye edilen kriterlere göre normal dağılım göstermeyen özelliklere ilişkin veri setleri semivaryogram analizinden önce logaritmik ya da karekök dönüşümüne tabi tutularak dağılım normal dağılıma yaklaştırılmıştır. Dönüşümlere rağmen normal dağılıma yaklaşmayan veri setlerinden ise uç değerlerden bazıları çıkarılarak verinin normal dağılıma yaklaşması sağlanmıştır (Ersahin et al., 2017). Daha sonra toprak değişkenlerinin uzaysal yapısı modellenmiş ve son olarak teorik semivaryogramlara ilişkin parametreler kullanılarak (nugget, sill, range) bayağı (ordinary) nokta krigleme yöntemi ile değişkenlerin uzaysal enterpolasyonu yapılmış ve yüzey haritaları oluşturulmuştur (Isaaks and Srivastava, 1989).

Toprak değişkenleri için en uygun semivaryogramın elde edilmesinde değişken lag aralıkları kullanılmış, aktif lag mesafesi olarak çalışma alanlarının en kısa ekseninin yarısı olan mesafeler alınmıştır. Bu bağlamda karışık meşcere için $105 \mathrm{~m}$ saf meşcere için ise $120 \mathrm{~m}$ aktif lag mesafesi olarak alınmıştır. Semivayogramın modellenmesinde modelin uygunluğu ve başarısı determinasyon katsayısı $\left(\mathrm{R}^{2}\right)$, hata kareler toplamı (RSS) ve çapraz değerlendirme korelasyon katsayısı (r) ile kontrol edilmiştir (Isaaks and Srivastava, 1989). Bu bağlamda, en yüksek $R^{2}$ ve $r$ ile en düşük RSS değerlerini veren model tipi ve lag aralıkları tercih edilmiştir.

Değişkenler için hesaplanan nugget $\left(\mathrm{C}_{0}\right)$, range ve sill $\left(\mathrm{C}_{\mathrm{s}}\right)$ değerleri kullanılarak nispi (yüzde) nugget etkisi $\left(\left(\mathrm{C}_{0} / \mathrm{C}_{\mathrm{s}}\right) \times 100\right)$ hesaplanmış ve daha sonra bu değer ilgili değişkenlerin uzaysal bağımlılık derecesinin belirlenmesinde kullanılmıştır. Şayet nugget etkisi \%25 ve altında ise değişken kuvvetli uzaysal bağımlı, \%25-75 arasında orta derecede uzaysal bağımlı ve \%75 ve üzerinde ise zayıf uzaysal bağımlı olarak nitelendirilmiştir (Cambardella et al.,1994).

Toprak değişkenleri için elde edilen teorik semivaryogramlara ilişkin parametreler (nugget, sill ve range) kullanılarak bayağı nokta krigleme (ordinary point kriging) yöntemiyle toprak özelliklerinin çalışma alanındaki yüzey haritaları oluşturulmuştur. Krigleme haritalarının güvenilirliğinin değerlendirilmesinde çapraz değerlendirme korelasyon katsayısı (r), nispi ortalama mutlak hata (relative mean absolute error: RMAE) ve nispi hata kareleri karekök ortalaması (relative root mean square error: RRMSE) ile kontrol edilmiştir (Li and Heap, 2011). Kriglemede semivaryogramın range mesafesi de dikkate alınarak hesaplamalarda minimum 10 ve maksimum 16 komşu kullanılmıştır (Isaaks and Srivastava, 1989).

\section{Bulgular ve Tartışma}

\subsection{Toprak Özelliklerinin Tanımsal İstatistikleri}

Çalışma alanının genelinde toprak özelliklerine ilişkin tanımsal istatistikler incelendiğinde, en yüksek değişkenliğin alınabilir fosforda en düşük değişkenliğin ise toprak pH'sında olduğu görülmektedir (Tablo 1). Toprak tekstüründeki değişkenlik hem meşcere hem de derinlikler arasında fazla bir farklılık göstermemiştir (Tablo 1). Tablo 1'den toprak özelliklerinin büyük bir kısmına ilişkin değişkenliğin de tıpkı toprak tekstür bileşenlerinde olduğu gibi toprak derinlikleri ve meşcereler arasında benzer davrandığı görülmektedir. Ancak, genellikle toprak özelliklerinin her iki meşcerede de $0-15 \mathrm{~cm}$ derinlikte daha değişken olduğu söylenebilir. Burada bitki örtüsünden kaynaklanan değişkenliğin ve mikro topografyanın neden olduğu taşınma-birikme süreçlerinin üst topraklarda alt topraklara göre daha etkili olduğu düşünülmektedir. Nitekim arazi çalışması esnasında, mikro topografyanın etkisinin, özellikle ölü örtü ayrışması ve taşınma-birikme olaylarının neden olduğu heterojenliğin derinlikle azaldığının tarafımızdan gözlenmiş olması bu görüşü desteklemektedir. Gül and Erşahin (2019) tarafından çam ormanı, meşe ormanı ve tarım alanlarının bulunduğu 1000 ha'lık alanda yapılan bir çalışmada özellikle meşe ve çam alanlarında organik madde değişkenliğinin yüksek olmasında ölü örtü tabakasının kalınlığı ve yüksekliği, ölü örtünün ayrışma derecesi, örnekleme noktalarının bulunduğu meşcere tipi, meşcere kapalılığı ve topoğrafyanın etkili olduğu belirtilmiştir. Üst toprağın daha değişken olması, özellikle orman ve mera alanlarına özgü olup tarım alanlarında toprak işlemenin etkisi nedeniyle tersi bir durum gözlenebilir. Örneğin, Ersahin and Brohi (2006) Kazova'da (Tokat) işlenen bir tarım arazisinde yapmış oldukları bir çalışmada toprak özelliklerinin 30-60 cm derinliğindeki değişkenliğinin 0-30 cm toprak derinliğindeki değişkenliğe kıyasla daha fazla olduğunu rapor etmişlerdir. Benzer durum Ongun (2008) tarafından Menemen (İzmir) ovasında yapılan bir çalışma soncunda da rapor edilmiştir. 
Varyasyon katsayısının tersine, önemli bir dağılım ölçüsü olarak kabul edilen çarpıklığın (Ott, 1993) meşcere ve derinlikleri bakımından farklı değerler aldığı görülmektedir (Tablo 1). Örneğin, saf meşcerede 0-15 cm derinlikte hacim ağırlığı şiddetli sola çarpık ve yayvan (Webster, 2001) iken, diğer üç veri setinde normale yakın bir dağılım göstermektedir (Tablo 1). Benzer durum silt, OM, TK ve YSİ için de söylenebilir. Bu durumun saf ve karışık şecerelerdeki mikro topografyadaki farklılıktan ileri geldiği düşünülmektedir.

Tablo 1. Karışık ve saf meşcerede $0-15$ ve $15-30 \mathrm{~cm}$ derinlikler için toprak özelliklerinin tanımlayıcı istatistikleri.

\begin{tabular}{|c|c|c|c|c|c|c|c|c|}
\hline Özellik & MT & EK & EB & AO & SS & Çarpıklık & Basıklık & $\begin{array}{l}\text { VK } \\
(\%)\end{array}$ \\
\hline \multirow{4}{*}{$\begin{array}{l}\text { HA } \\
\text { g/cm }\end{array}$} & KM (0-15 cm) & 0,70 & 1,70 & 1,14 & 0,21 & 0,23 & $-0,14$ & 18,42 \\
\hline & KM (15-30 cm) & 0,80 & 1,81 & 1,34 & 0,19 & $-0,05$ & 0,37 & 14,18 \\
\hline & $\mathrm{SM}(0-15 \mathrm{~cm})$ & 0,28 & 1,37 & 1,04 & 0,17 & $-1,05$ & 2,54 & 16,35 \\
\hline & SM $(15-30 \mathrm{~cm})$ & 0,75 & 1,65 & 1,18 & 0,17 & $-0,09$ & $-0,05$ & 14,41 \\
\hline \multirow{4}{*}{$\mathbf{p H}$} & $\mathrm{KM}(0-15 \mathrm{~cm})$ & 4,49 & 7,21 & 5,48 & 0,58 & 0,85 & 0,89 & 10,58 \\
\hline & KM (15-30 cm) & 4,36 & 7,16 & 5,36 & 0,57 & 0,94 & 0,95 & 10,63 \\
\hline & $\mathrm{SM}(0-15 \mathrm{~cm})$ & 4,53 & 7,08 & 5,52 & 0,54 & 0,27 & $-0,46$ & 9,78 \\
\hline & SM $(15-30 \mathrm{~cm})$ & 4,57 & 6,86 & 5,40 & 0,50 & 0,49 & $-0,30$ & 9,26 \\
\hline \multirow{4}{*}{$\begin{array}{l}\text { EC } \\
(\mu \mathrm{s} / \mathrm{cm})\end{array}$} & $\mathrm{KM}(0-15 \mathrm{~cm})$ & 73,70 & 437,00 & 163,36 & 69,70 & 1,75 & 3,23 & 42,67 \\
\hline & KM $(15-30 \mathrm{~cm})$ & 12,00 & 354,00 & 108,49 & 59,14 & 2,31 & 5,99 & 54,51 \\
\hline & $\mathrm{SM}(0-15 \mathrm{~cm})$ & 76,80 & 509,00 & 181,40 & 70,83 & 1,43 & 3,75 & 39,05 \\
\hline & SM $(15-30 \mathrm{~cm})$ & 58,60 & 350,00 & 146,04 & 63,24 & 1,15 & 1,01 & 43,30 \\
\hline \multirow{4}{*}{ Kum (\%) } & KM $(0-15 \mathrm{~cm})$ & 25,50 & 63,00 & 43,34 & 7,12 & 0,47 & 0,20 & 16,43 \\
\hline & KM $(15-30 \mathrm{~cm})$ & 25,50 & 58,00 & 38,71 & 6,32 & 0,60 & 0,52 & 16,33 \\
\hline & $\mathrm{SM}(0-15 \mathrm{~cm})$ & 28,90 & 65,50 & 47,80 & 6,35 & $-0,14$ & 0,23 & 13,28 \\
\hline & SM $(15-30 \mathrm{~cm})$ & 13,00 & 60,50 & 45,30 & 6,95 & $-0,82$ & 3,47 & 15,34 \\
\hline \multirow{4}{*}{ Kil (\%) } & KM (0-15 cm) & 24,05 & 54,75 & 36,46 & 5,19 & 0,44 & 0,78 & 14,23 \\
\hline & KM (15-30 cm) & 6,10 & 52,50 & 39,50 & 5,60 & $-0,80$ & 8,43 & 14,18 \\
\hline & $\mathrm{SM}(0-15 \mathrm{~cm})$ & 18,60 & 52,00 & 33,38 & 4,79 & 0,30 & 1,87 & 14,35 \\
\hline & SM $(15-30 \mathrm{~cm})$ & 21,10 & 45,00 & 35,15 & 4,76 & $-0,28$ & 0,28 & 13,54 \\
\hline \multirow{4}{*}{ Silt (\%) } & KM $(0-15 \mathrm{~cm})$ & 8,85 & 35,45 & 20,18 & 4,45 & $-0,03$ & 3,71 & 22,05 \\
\hline & KM $(15-30 \mathrm{~cm})$ & 9,50 & 58,40 & 21,77 & 6,02 & 2,09 & 11,74 & 27,65 \\
\hline & $\mathrm{SM}(0-15 \mathrm{~cm})$ & 9,55 & 31,80 & 18,82 & 4,06 & 0,29 & 0,58 & 21,57 \\
\hline & SM $(15-30 \mathrm{~cm})$ & 7,50 & 45,45 & 19,54 & 4,82 & 0,81 & 6,65 & 24,67 \\
\hline \multirow{4}{*}{$\begin{array}{l}\mathrm{CaCO}_{3} \\
(\%)\end{array}$} & KM (0-15 cm) & 1,40 & 4,40 & 2,17 & 0,43 & 2,48 & 8,45 & 19,82 \\
\hline & KM $(15-30 \mathrm{~cm})$ & 1,60 & 4,00 & 2,15 & 0,29 & 2,96 & 16,35 & 13,49 \\
\hline & $\mathrm{SM}(0-15 \mathrm{~cm})$ & 1,30 & 3,80 & 2,39 & 0,39 & 1,17 & 3,09 & 16,32 \\
\hline & SM $(15-30 \mathrm{~cm})$ & 1,80 & 4,30 & 2,36 & 0,39 & 1,69 & 5,34 & 16,53 \\
\hline \multirow{4}{*}{$\begin{array}{l}\text { OM } \\
(\%)\end{array}$} & KM (0-15 cm) & 3,27 & 13,33 & 9,68 & 2,20 & $-0,36$ & $-0,05$ & 22,73 \\
\hline & KM $(15-30 \mathrm{~cm})$ & 2,60 & 12,71 & 6,48 & 1,94 & 0,76 & 1,06 & 29,94 \\
\hline & $\mathrm{SM}(0-15 \mathrm{~cm})$ & 1,53 & 13,45 & 10,90 & 2,74 & $-1,58$ & 2,41 & 25,14 \\
\hline & SM $(15-30 \mathrm{~cm})$ & 2,76 & 13,45 & 8,86 & 2,53 & $-0,24$ & $-0,48$ & 28,56 \\
\hline \multirow{4}{*}{$\begin{array}{l}\text { P } \\
\left(\mathrm{cmolkg}^{-1}\right)\end{array}$} & KM (0-15 cm) & 0,03 & 0,46 & 0,15 & 0,08 & 1,53 & 3,14 & 53,33 \\
\hline & KM $(15-30 \mathrm{~cm})$ & 0,02 & 0,53 & 0,10 & 0,07 & 2,91 & 12,63 & 70,00 \\
\hline & $\mathrm{SM}(0-15 \mathrm{~cm})$ & 0,03 & 0,93 & 0,16 & 0,11 & 3,83 & 23,35 & 68,75 \\
\hline & SM $(15-30 \mathrm{~cm})$ & 0,04 & 0,48 & 0,13 & 0,08 & 1,96 & 4,83 & 61,54 \\
\hline \multirow{4}{*}{ TK (\%) } & KM (0-15 cm) & 16,45 & 47,30 & 28,80 & 7,27 & 0,28 & $-0,48$ & 25,24 \\
\hline & KM $(15-30 \mathrm{~cm})$ & 14,36 & 46,62 & 25,88 & 6,14 & 0,62 & 0,54 & 23,72 \\
\hline & $\mathrm{SM}(0-15 \mathrm{~cm})$ & 11,92 & 56,98 & 29,41 & 8,78 & 0,68 & 0,51 & 29,85 \\
\hline & SM $(15-30 \mathrm{~cm})$ & 10,16 & 55,71 & 26,12 & 6,76 & 1,15 & 3,27 & 25,88 \\
\hline \multirow{4}{*}{ SN (\%) } & $\mathrm{KM}(0-15 \mathrm{~cm})$ & 3,37 & 29,42 & 15,75 & 4,48 & 0,08 & 0,71 & 28,44 \\
\hline & KM $(15-30 \mathrm{~cm})$ & 4,04 & 27,32 & 13,78 & 4,05 & 0,55 & 0,89 & 29,39 \\
\hline & $\mathrm{SM}(0-15 \mathrm{~cm})$ & 0,90 & 28,31 & 17,76 & 5,07 & $-0,51$ & 0,59 & 28,55 \\
\hline & SM $(15-30 \mathrm{~cm})$ & 0,80 & 34,29 & 15,22 & 4,96 & $-0,04$ & 2,49 & 32,59 \\
\hline \multirow{4}{*}{ YSİ (\%) } & $\mathrm{KM}(0-15 \mathrm{~cm})$ & 1,88 & 29,36 & 13,04 & 5,77 & 0,29 & $-0,11$ & 44,25 \\
\hline & KM $(15-30 \mathrm{~cm})$ & 1,69 & 25,08 & 12,10 & 5,31 & 0,29 & $-0,41$ & 43,88 \\
\hline & $\mathrm{SM}(0-15 \mathrm{~cm})$ & 2,16 & 38,83 & 11,65 & 6,68 & 1,39 & 2,84 & 57,34 \\
\hline & $\mathrm{SM}(15-30 \mathrm{~cm})$ & 1,71 & 31,85 & 10,90 & 5,07 & 0,98 & 2,02 & 46,51 \\
\hline
\end{tabular}

MT: Meșcere tipi, AO: Aritmetik ortalama, SS: Standart sapma, EK: En küçük, EB: en büyük, SM: Saf meșcere, KM: Karıșık meșcere, HA: Hacim ağırlığı $\left(\mathrm{g} / \mathrm{cm}^{-3}\right)$, EC: elektriksel iletkenlik ( $\left.\mu \mathrm{s} / \mathrm{cm}\right)$ OM: Organik madde (\%), P: Alınabilir Fosfor (cmolkg $\left.{ }^{-1}\right)$, TK: Tarla kapasitesi (\%), SN: Solma noktası (\%), YSİ: Yarayışlı su içeriği (\%), VK: Varyasyon katsayısı.

\subsection{Toprak Özelliklerinin Uzaysal Yapısı}

Çalışma alanında toprak özelliklerine ilişkin toplam 48 adet deneysel semivaryogramın modellenmesinde üssel (exponential), küresel (spherical), Gausian ve nugget modeller kullanılmıştır. Küresel model orijin yakınlarında doğrusal (linear) davranır daha sonra hızla yükselir ve bir sill değerine ulaşır. Üssel model de aynı şekilde orijin yakınlarında linear davranır ve daha sonra hızla yükselir ancak sill değerine çok daha yavaş, asimptotik olarak yaklaşır. Gaussian model orijin yakınlarında parabolik davranır, daha sonra hızla yükselerek tıpkı üssel modelde 
olduğu gibi asimptotik olarak bir sill değerine yaklaşır. Saf nugget model için ise bir sill ve range değeri geçerli değildir (Isaaks and Srivastava, 1989). Toprak özelliklerinin uzaysal yapısını karakterize etmeleri açısından model tipi önemlidir.

Toprak özelliklerinin uzaysal yapısı her iki alan ve derinlikte de farklılık göstermektedir. Karışık meşcerede toprak özelliklerinin deneysel semivaryogramlarının modellenmesinde üssel model daha iyi uyum gösterirken, saf meşcerede küresel modelin daha uygun olduğu görülmüştür. Karışık meşceredeki 24 deneysel semivaryogramdan 8'i küresel, 9’u üssel, 5’i Gaussian ve 2'si de saf nugget model ile modellenirken; saf meşcerede 10'u küresel, 9'u üssel, 4'ü Gaussian ve 1'i de saf nugget model ile modellenmiştir. Diğer taraftan, 0-15 cm toprak derinliğinde üssel model deneysel semivaryogramların \%50'sinin, 15-30 cm derinliğinde ise küresel model \%59'unun modellenmesinde kullanılmıştır. Gaussian model ise daha az sayıda deneysel semivaryograma uyumlu bulunmuştur (Tablo 2).

Jeoistatistiksel range mesafesi (Ao) bir değişkenin uzaysal olarak otokorele olduğu maksimum mesafeyi bildirir. Genellikle her iki meşcerede de Ao 0-15 cm derinlikte, 15-30 cm derinlikte olduğundan daha yüksektir. Benzer örnekleme deseni ve sıklığı kullanılarak yapılan diğer çalışmalarla (Erşahin, 1999; Akbaş, 2004; Sağlam, 2008; Gül, 2015) karşılaştırıldığında bu çalışmada elde edilen Ao değerlerinin genellikle çok daha düşük olduğu görülmekte olup, bunun nedeni diğer çalışmaların düz veya düze yakın tarım alanlarında, bu çalışmanın ise engebeli orman alanında yapılmış olmasına bağlanabilir. Nitekim Gül (2015) tarafından çam, meşe ve tarım alanlarının bulunduğu 1000 ha'lık alanda yapılan bir çalışmada, benzer örnekleme deseni ve sıklığında çölleşme riski (environmmental sensitivity index) için Ao tarım arazisinde $666 \mathrm{~m}$, meşe ormanlarında $75 \mathrm{~m}$ ve çam ormanlarında ise $96 \mathrm{~m}$ bulunmuştur. Kuzeybatı İspanya'da farklı toprak özelliklerinin uzaysal değişkenliğinin araştırıldığı ormanlık bir alanda, Ao’’n kısa olup, 3,86 m ile 18,51 m arasında değiştiği rapor edilmiştir (Gallardo, 2003). Fundalık ve mera bitki topluluklarının karşılaştırıldığı bir çalışmada iki farklı bitki topluluğu altındaki arazilerde 0-10 cm toprak derinliğinden alınan fosfor için Ao'ın 20,91 m olduğu belirtilmiştir (Gallardo and Parama, 2007). Buradan hareketle toprak özellikleri için Ao’’n bitki örtüsü, topografya ve arazi kullanımı tarafından oldukça etkilendiği düşünülebilir. Diğer taraftan, yapılacak karşılaştırmalarda örnekleme deseni ve sıklığının Ao üzerine etkisi de mutlaka dikkate alınmalıdır.

Tablo 2. Toprak özelliklerine ilişkin semivaryogram modeli, model parametreleri ve çapraz değerlendirme sonuçları.

\begin{tabular}{|c|c|c|c|c|c|c|c|c|c|}
\hline Özellik & $\begin{array}{l}\text { Meşcere } \\
\text { Tipi }\end{array}$ & Model & $\begin{array}{l}\text { Co } \\
\text { (Nugget) }\end{array}$ & $\begin{array}{l}\mathrm{Co}+\mathrm{C} \\
\text { (Sill) }\end{array}$ & $\begin{array}{l}\text { Ao (m) } \\
\text { (Range) }\end{array}$ & $\begin{array}{l}\mathrm{Co} /(\mathrm{Co}+\mathrm{C}) \\
\times 100\end{array}$ & $\overline{\mathbf{R}^{2}}$ & $\mathbf{r}$ & RSS \\
\hline \multirow{4}{*}{$\begin{array}{l}\text { HA } \\
\mathrm{g} / \mathrm{cm}^{3}\end{array}$} & $\begin{array}{l}\mathrm{KM} \\
(0-15 \mathrm{~cm})\end{array}$ & Exponential & 0,02321 & 0,04652 & 25,50 & 49,89 & 0,608 & 0,23 & $8,51 \times 10^{-5}$ \\
\hline & $\begin{array}{l}\text { KM } \\
(15-30 \mathrm{~cm})\end{array}$ & Guassian & 0,0020 & 0,359 & 8,31 & 0,56 & 0,732 & 0,08 & $6,61 \times 10^{-5}$ \\
\hline & $\begin{array}{l}\text { SM } \\
(0-15 \mathrm{~cm})\end{array}$ & Spherical & 0,0001 & 0,0474 & 8,00 & 0,21 & 0,268 & 0,25 & $8,61 \times 10^{-4}$ \\
\hline & $\begin{array}{l}\text { SM } \\
(15-30 \mathrm{~cm})\end{array}$ & Spherical & 0,01064 & 0,02928 & 16,20 & 36,34 & 0,674 & 0,09 & $5,64 \times 10^{-5}$ \\
\hline \multirow[t]{4}{*}{ pH } & $\begin{array}{l}\text { KM } \\
(0-15 \mathrm{~cm})\end{array}$ & Exponential & 0,00718 & 0,01446 & 29,70 & 49,65 & 0,744 & 0,10 & $5,62 \times 10^{-6}$ \\
\hline & $\begin{array}{l}\text { KM } \\
(15-30 \mathrm{~cm})\end{array}$ & Guassian & 0,00001 & 0,01482 & 5,60 & 0,07 & 0,584 & 0,10 & $8,09 \times 10^{-5}$ \\
\hline & $\begin{array}{l}\text { SM } \\
(0-15 \mathrm{~cm})\end{array}$ & Exponential & 0,1372 & 0,2754 & 47,10 & 49,82 & 0,674 & 0,18 & $3,65 \times 10^{-3}$ \\
\hline & $\begin{array}{l}\text { SM } \\
(15-30 \mathrm{~cm})\end{array}$ & Guassian & 0,0001 & 0,2432 & 7,62 & 0,04 & 0,136 & 0,002 & $7,62 \times 10^{-3}$ \\
\hline \multirow{4}{*}{$\begin{array}{l}\text { EC } \\
\text { ( } \mu \mathrm{s} / \mathrm{cm})\end{array}$} & $\begin{array}{l}\text { KM } \\
(0-15 \mathrm{~cm})\end{array}$ & Saf nugget & 14,231 & 14,231 & 135,45 & 100 & 0,415 & 0,05 & $2,88 \times 10^{-3}$ \\
\hline & $\begin{array}{l}\text { KM } \\
(15-30 \mathrm{~cm})\end{array}$ & Guassian & 0,0001 & 0,2012 & 7,96 & 0,05 & 0,377 & 0,19 & 0,0181 \\
\hline & $\begin{array}{l}\text { SM } \\
(0-15 \mathrm{~cm})\end{array}$ & Exponential & 0,0548 & 0,1386 & 7,20 & 39,54 & 0,711 & 0,10 & $4,63 \times 10^{-5}$ \\
\hline & $\begin{array}{l}\text { SM } \\
(15-30 \mathrm{~cm})\end{array}$ & Spherical & 0,0001 & 0,1752 & 8,70 & 0,06 & 0,670 & 0,16 & $1,59 \times 10^{-3}$ \\
\hline \multirow{4}{*}{$\begin{array}{l}\text { Kum } \\
(\%)\end{array}$} & $\begin{array}{l}\text { KM } \\
(0-15 \mathrm{~cm})\end{array}$ & Guassion & 16,28 & 47,01 & 37,58 & 34,63 & 0,959 & 0,26 & 47,2 \\
\hline & $\begin{array}{l}\mathrm{KM} \\
(15-30 \mathrm{~cm})\end{array}$ & Exponential & 6,78 & 38,03 & 68,40 & 17,83 & 0,913 & 0,46 & 67,8 \\
\hline & $\begin{array}{l}\text { SM } \\
(0-15 \mathrm{~cm})\end{array}$ & Exponential & 18,46 & 42,27 & 109,5 & 43,67 & 0,955 & 0,32 & 17,6 \\
\hline & $\begin{array}{l}\text { SM } \\
(15-30 \mathrm{~cm})\end{array}$ & Spherical & 0,90 & 37,29 & 13,60 & 2,41 & 0,735 & 0,32 & 134, \\
\hline
\end{tabular}

Tablo 2. devam ediyor.

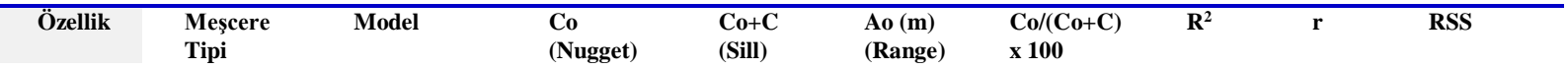




\begin{tabular}{|c|c|c|c|c|c|c|c|c|c|}
\hline \multirow{4}{*}{$\begin{array}{l}\text { Kil } \\
(\%)\end{array}$} & $\begin{array}{l}\mathrm{KM} \\
(0-15 \mathrm{~cm})\end{array}$ & Guassian & 6,54 & 28,32 & 17,49 & 23,09 & 0,788 & 0,25 & 84,1 \\
\hline & $\begin{array}{l}\text { KM } \\
(15-30 \mathrm{~cm})\end{array}$ & Spherical & 0,01 & 30,77 & 8,60 & 0,03 & 0,340 & 0,03 & 6,63 \\
\hline & $\begin{array}{l}\text { SM } \\
(0-15 \mathrm{~cm})\end{array}$ & Guassian & 0,01 & 23,25 & 9,17 & 0,04 & 0,652 & 0,08 & 85,2 \\
\hline & $\begin{array}{l}\text { SM } \\
(15-30 \mathrm{~cm})\end{array}$ & Spherical & 14,95 & 31,80 & 25,0 & 47,01 & 0,684 & 0,27 & 81,4 \\
\hline \multirow{4}{*}{$\begin{array}{l}\text { Silt } \\
\text { (\%) }\end{array}$} & $\begin{array}{l}\text { KM } \\
(0-15 \mathrm{~cm})\end{array}$ & Exponential & 7,93 & 17,98 & 60,60 & 44,10 & 0,629 & 0,03 & 32,0 \\
\hline & $\begin{array}{l}\mathrm{KM} \\
(15-30 \mathrm{~cm})\end{array}$ & Spherical & 0,0001 & 0,0912 & 8,40 & 0,11 & 0,291 & 0,18 & $8,23 \times 10^{-3}$ \\
\hline & $\begin{array}{l}\text { SM } \\
(0-15 \mathrm{~cm})\end{array}$ & Exponential & 7,89 & 15,79 & 89,4 & 49,97 & 0,688 & 0,44 & 25,6 \\
\hline & $\begin{array}{l}\text { SM } \\
(15-30 \mathrm{~cm})\end{array}$ & Spherical & 0,10 & 18,970 & 9,87 & 0,53 & 0,608 & 0,002 & 86 \\
\hline \multirow{4}{*}{$\begin{array}{l}\mathrm{CaCO}_{3} \\
(\%)\end{array}$} & $\begin{array}{l}\text { KM } \\
(0-15 \mathrm{~cm})\end{array}$ & Saf nugget & 0,36924 & 0,3694 & 135,45 & 99,96 & 0,254 & 0,03 & $1,81 \times 10^{-3}$ \\
\hline & $\begin{array}{l}\mathrm{KM} \\
(15-30 \mathrm{~cm})\end{array}$ & Spherical & 0,0342 & 0,0763 & 24,20 & 44,82 & 0,738 & 0,06 & $3,77 \times 10^{-4}$ \\
\hline & $\begin{array}{l}\text { SM } \\
(0-15 \mathrm{~cm})\end{array}$ & Exponential & 0,01111 & 0,02232 & 27,0 & 49,78 & 0,488 & 0,37 & $3,51 \times 10^{-5}$ \\
\hline & $\begin{array}{l}\text { SM } \\
(15-30 \mathrm{~cm})\end{array}$ & Spherical & 0,00001 & 0,02492 & 8,00 & 0,04 & 0,230 & 0,23 & $4,94 \times 10^{-4}$ \\
\hline \multirow{4}{*}{$\begin{array}{l}\text { OM } \\
(\%)\end{array}$} & $\begin{array}{l}\text { KM } \\
(0-15 \mathrm{~cm})\end{array}$ & Spherical & 0,30000 & $\begin{array}{l}4,63100 \\
1\end{array}$ & 10,10 & 6,48 & 0,841 & 0,16 & 0,419 \\
\hline & $\begin{array}{l}\text { KM } \\
(15-30 \mathrm{~cm})\end{array}$ & Guassian & 0,0001 & 0,1352 & 10,21 & 0,07 & 0,605 & 0,05 & $6,25 \times 10^{-3}$ \\
\hline & $\begin{array}{l}\text { SM } \\
(0-15 \mathrm{~cm})\end{array}$ & Exponential & 1,480 & 6,712 & 4,38 & 22,05 & 0,838 & 0,24 & 3,40 \\
\hline & $\begin{array}{l}\text { SM } \\
(15-30 \mathrm{~cm})\end{array}$ & Spherical & 0,84 & 6,34 & 11,90 & 13,25 & 0,828 & 0,18 & 1,13 \\
\hline \multirow{4}{*}{$\begin{array}{l}\mathbf{P} \\
(\mathbf{c m o l} \\
\left.\mathrm{kg}^{-1}\right)\end{array}$} & $\begin{array}{l}\text { KM } \\
(0-15 \mathrm{~cm})\end{array}$ & Guassion & 0,0631 & 0,2392 & 16,62 & 26,37 & 0,751 & 0,23 & $6,54 \times 10^{-3}$ \\
\hline & $\begin{array}{l}\text { KM } \\
(15-30 \mathrm{~cm})\end{array}$ & Exponential & 0,0855 & 0,3540 & 48,30 & 24,15 & 0,879 & 0,18 & $6,16 \times 10^{-3}$ \\
\hline & $\begin{array}{l}\text { SM } \\
(0-15 \mathrm{~cm})\end{array}$ & Spherical & 0,1239 & 0,2928 & 46,70 & 42,32 & 0,949 & 0,25 & $1,42 \times 10^{-3}$ \\
\hline & $\begin{array}{l}\text { SM } \\
(15-30 \mathrm{~cm})\end{array}$ & Guassian & 0,001 & 0,318 & 9,87 & 0,31 & 0,723 & 0,42 & 0,0143 \\
\hline \multirow{4}{*}{$\begin{array}{l}\text { TK } \\
(\%)\end{array}$} & $\begin{array}{l}\mathrm{KM} \\
(0-15 \mathrm{~cm})\end{array}$ & Exponential & 7,00 & 46,69 & 16,50 & 14,99 & 0,742 & 0,31 & 84,2 \\
\hline & $\begin{array}{l}\mathrm{KM} \\
(15-30 \mathrm{~cm})\end{array}$ & Spherical & 0,001 & 0,323 & 8,50 & 0,31 & 0,374 & 0,07 & 0,0332 \\
\hline & $\begin{array}{l}\text { SM } \\
(0-15 \mathrm{~cm})\end{array}$ & Exponential & 18,90 & 70,69 & 30,9 & 26,74 & 0,812 & 0,27 & 268 \\
\hline & $\begin{array}{l}\text { SM } \\
(15-30 \mathrm{~cm})\end{array}$ & Guassain & 0,0001 & 0,0766 & 8,31 & 0,13 & 0,487 & 0,11 & $1,66 \times 10^{-3}$ \\
\hline \multirow{4}{*}{$\begin{array}{l}\text { SN } \\
\text { (\%) }\end{array}$} & $\begin{array}{l}\text { KM } \\
(0-15 \mathrm{~cm})\end{array}$ & Spherical & 3,260000 & 19,00 & 9,10 & 17,16 & 0,237 & 0,028 & 57,01 \\
\hline & $\begin{array}{l}\text { KM } \\
(15-30 \mathrm{~cm})\end{array}$ & Spherical & 0,01000 & 13,96 & 8,30 & 0,07 & 0,306 & 0,039 & 94,6 \\
\hline & $\begin{array}{l}\text { SM } \\
(0-15 \mathrm{~cm})\end{array}$ & Spherical & 0,010 & 27,21 & 8,40 & 0,04 & 0,493 & 0,036 & 138 \\
\hline & $\begin{array}{l}\text { SM } \\
(15-30 \mathrm{~cm})\end{array}$ & Spherical & 0,01 & 30,090 & 80,10 & 0,03 & 0,242 & 0,009 & 1314 \\
\hline \multirow{4}{*}{$\begin{array}{l}\text { YSI } \\
(\%)\end{array}$} & $\begin{array}{l}\mathrm{KM} \\
(0-15 \mathrm{~cm})\end{array}$ & Exponential & 6,96 & 32,41 & 10,10 & 21,7 & 0,839 & 0,39 & 48,9 \\
\hline & $\begin{array}{l}\mathrm{KM} \\
(15-30 \mathrm{~cm})\end{array}$ & Exponential & 12,48 & 26,23 & 46,50 & 47,58 & 0,743 & 0,3 & 41,7 \\
\hline & $\begin{array}{l}\text { SM } \\
(0-15 \mathrm{~cm})\end{array}$ & Guassian & 0,0001 & 0,2922 & 8,66 & 0,03 & 0,756 & 0,15 & $5,29 \times 10^{-3}$ \\
\hline & $\begin{array}{l}\text { SM } \\
(15-30 \mathrm{~cm})\end{array}$ & Saf nugget & 0,6281 & 0,6281 & 167,03 & 100 & 0,667 & 0,76 & 0,0104 \\
\hline
\end{tabular}

SM: Saf meşcere, KM: Karışık meşcere, HA: Hacim ağırlığı (g/cm³), EC: elektriksel iletkenlik ( $\mu \mathrm{s} / \mathrm{cm})$, OM: Organik madde (\%), P: Alınabilir fosfor (cmol kg-1), TK: Tarla kapasitesi (\%), SN: Solma noktası (\%), YSİ: Yarayışlı su içeriği (\%), VK: Varyasyon katsayısı, A: Range (m), C: Yapısal semivaryans, Co: Külçe (nugget) varyans, $\mathrm{R}^{2}=$ Regresyon determinasyon Katsayısı, $r=$ Çapraz değerlendirme korelasyon katsayısı, RSS: Hata kareler toplamı, SM: Saf meşcere, KM: Karışık meşcere, Co/(Co+C)x100=Nugget etkisi

Nugget varyans $\left(\mathrm{C}_{0}\right)$, mevcut örnekleme sıklığı ve deseninde mesafeye bağlı olarak açıklanamayan varyans olarak tanımlanmıştır (Isaaks and Srivastava, 1989). Nugget varyans, örnekleme aralıklarının yeterince kısa tutulmaması, mikro topoğrafyadaki sık ve ani değiş̧iklikler, örneklerin laboratuvar analizinde yapılan hatalar ve GPS koordinatlarının alınmasında yapılan kaydırmalar da dahil olmak üzere birçok faktörden kaynaklanabilir (Mualla and McBratney, 2000; Gregory et al., 2006). Nugget etkisi nugget varyansın sill (Cs)'e oranı olup, yüzde olarak ifade edilir. Bizim çalışmamızda, toprak özelliklerine ilişkin nugget etkisi genelde yüksek olup, bunun nedeni mikro topoğrafyanın son derece değişken olması ve buna bağlı olarak orman altı bitki örtüsünün kısa mesafelerde aşırı değişken olmasına bağlanabilir. Özellikle nugget etkisinin her iki meşcerede de 0-15 cm derinlikte pH, EC, kum, silt, $\mathrm{CaCO}_{3}, \mathrm{P}$ ve TK için çok daha yüksek olması bu tezimizi desteklemektedir. Ancak nugget etkisi bakımından meşcereler arasında sistematik bir farklılık gözlenmemiştir. 
Semivaryogramın $\mathrm{A}_{0}$ değerine karşılık aldığı değer sill $\left(\mathrm{C}_{s}\right)$ olarak adlandırılır. Sill, tıpkı $\mathrm{A}_{0}$ değerlerinde olduğu gibi 0-15 cm'de genellikle yüksek değerler almıştır. Ancak, toprak özelliklerine ilişkin $\mathrm{C}_{\mathrm{s}}$ değerlerinin genel varyans değerinin altında olması, toprak özellikleri için uzaysal yapıda global (genel) bir trend olmadığını göstermektedir (Trangmar et al., 1985; Ersahin et al., 2017). Diğer taraftan, toprak özelliklerine ilişkin izotropik semivaryogramlar için hesaplanan $\mathrm{A}_{0}$ değerlerinin çalışma alanlarının en kısa ekseni olan, karışık meşcerede 105 $\mathrm{m}$ ve saf meşcerede 120 m'den daha kısa olması, seçilen çalışma alanının hedeflenen çalışma için yeterince geniş olduğunu göstermektedir.

Nugget etkisi aynı zamanda ilgili özelliğin uzaysal bağımlılık şiddetinin belirlenmesinde de kullanılmaktadır (Cambardella et al., 1994). Cambardella et al. (1994) tarafindan önerilen sınıflamaya göre, şayet nugget etkisi $<\% 25$ ise ilgili özelliğin kuvvetli uzaysal bağımlı, \%25 ve \%75 arasında ise orta uzaysal bağımlı ve \%75 ve üzerinde ise zayıf uzaysal bağımlı olduğuna karar verilir. Bu bağlamda, toprak özelliklerinin üst topraklarda (0-15 $\mathrm{cm}$ ) genellikle orta ve zayıf uzaysal bağımlı, $15-30 \mathrm{~cm}$ derinlikte ise kuvvetli ve orta uzaysal bağımlı olduğu anlaşılmaktadır (Tablo 2). Üst toprakta $(0-15 \mathrm{~cm})$ uzaysal bağımlılığın daha düşük olmasının ise vejetasyon ile mikro topografya etkileşiminin $0-15 \mathrm{~cm}$ toprak derinliğinde daha belirleyici olmasına bağlanabilir. Nitekim bitki örtüsünün türü, yaşı ve sıklığı, toprağa giren organik maddenin miktarını ve niteliğini; toprakların ana materyal farklılıkları ve toprak taşınmasının şiddetinin ise toprak tekstür bileşenlerinin değiş̧kenliğini önemli derecede etkilediği belirtilmiştir (Charles and Garten, 2002). Uzaysal bağımlılı̆̆ın şiddeti açısında meşcereler arasında ise bir genelleme yapmak zordur.

Modelleme çalışmalarında en başarılı modelin elde edilmesine yönelik birçok alternatif denenmesine karşın, toprak özelliklerinin birçoğu için deneysel semivaryogramların modellenmesinde yeterince başarı elde edilememiştir. Tablo 2'de modelleme performans ölçütleri $\left(R^{2}, r\right.$ ve RSS) birlikte değerlendirildiğinde, çapraz değerlendirme korelasyon katsayısı $(r)$ ve determinasyon katsayısı $\left(R^{2}\right)$ nın genelde düşük olduğu görülmektedir. Buradan, teorik semivaryogramların ilgili deneysel semivaryogramları yeterince temsil edemediği söylenebilir. Bunun başlıca iki nedeninin olduğu düşünülmektedir: verinin fazla değişken ve nugget etkisinin yüksek olması. Nitekim Li and Heap (2011) ilgili özelliğin değişkenliği ve örnekleme yoğunluğu ile örnekleme deseninin tahmin başarısını etkileyen en önemli faktörler olduğunu belirtmişlerdir. Daha önce de belirtildiği üzere, nugget etkisinin yüksek olması bu alanda daha sık bir örnekleme yapılmasını gerekli kılmaktadır.

\subsection{Uzaysal Enterpolasyon (Krigleme)}

Uzaysal enterpolasyon, yani krigleme (kriging), jeoistatistiksel çalışmalarda önemli bir yere sahiptir. Krigleme ile ilgili değişkenin örneklenmeyen noktalardaki değerleri hesaplanarak yüzey haritası oluşturulur ve uzaysal değişim deseni analiz edilir. Uzaysal enterpolasyonda krigleme tahmin başarısının belirlenmesinde birçok farklı ölçüt kullanılmaktadır. Bunlar arasında aynı değişkene ilişkin ölçülen ve tahmin edilen verilerin dağılım ölçütlerinin karşılaştırılması (Isaaks and Srivastava, 1989) ve nispi mutlak hatalar ortalaması (RMAE), nispi mutlak hatalar karekökleri ortalaması (RRMSE) ve çapraz değerlendirme korelasyon katsayısı (r) yaygın olarak kullanılmaktadır (Li and Heap, 2011). Tıpkı semivaryogramın modellenmesinde olduğu gibi krigleme tahmininde de genellikle yeterince başarı elde edilememiştir. Tablo 3 incelendiğinde, toprak özelliklerine ilişkin ortalamaların tahmininde bayağı (ordinary) kriglemenin oldukça başarılı olduğu, ancak diğer dağılım ölçütlerine (standart sapma ve varyasyon katsayısı) bakıldığında buradaki başarının aslında yanıltıcı olduğu görülmektedir. Başarılı bir tahmin için sadece ölçülen ve tahmin edilen değerlerin ortalamalarının benzer olması yetmez, diğer dağılım ölçütlerinin de benzer olması gerekir. Tablo 3'den toprak özelliklerine ilişkin ölçülen ve tahmin edilen veri setlerinde standart sapma ve buna bağlı olarak hesaplanan değişkenlik katsayısı (VK) değerlerinin oldukça farklı olduğu dikkat çekmektedir. Değişkenlere ilişkin ortalamaların benzer olması krigleme yönteminin yüksek değerleri düşük, düşük değerleri de yüksek tahmin etme eğiliminden ileri gelmektedir (Isaaks and Srivastava, 1989). Tahmin edilen ve ölçülen değerlerin ilişkisinin bir ölçüsü olan çapraz değerlendirme korelasyon katsayısı (r) değerlerinin oldukça düşük olması bunun bir göstergesidir.

Özellikle, RMAE’nin \%10'un altına düştüğü tahminler başarılı sayıldığında (Li and Heap, 2011), Tablo 3'den az sayıda toprak özelliğinin kirgleme tahmininin başarılı sayılabileceği anlaşılmaktadır. Bunun nedeni ise daha önce de değinildiği gibi, değişkenlere ilişkin nugget varyans değerlerinin yüksek olmasıdır (Isaaks and Srivastava, 1989; Li and Heap, 2011). Kaldı ki, krigleme başarı ölçütü olarak kabul edilen çapraz değerlendirme korelasyon katsayısı (r) değerlerinin de oldukça düşük değerler aldığı dikkat çekmektedir. Aslında, $r$ değerlerinin yorumlanmasında oldukça temkinli davranılmalıdır. Çünkü r, veri setleri arasındaki benzerlikten ziyade ilişkiyi ölçmektedir. Yani, x değişkeninin yüksek değerlerine karşı y değeri de yüksek değerler alıyorsa aradaki ilişki pozitif ve yüksek düzeyde ilişkili demektir (Ott, 1993). Burada x ve y değişkenleri arasındaki doğrunun eğimi 1 'den çok daha farklı olsa bile ilişki kuvvetli olabilir. Yine de bir genelleme yapıldığında, kriglemenin az da olsa 
15-30 cm derinlikte daha başarılı sonuçlar verdiği görülmektedir.

Tablo 3. Saf ve karışık meşcerede toprak özelliklerine ilişkin krigleme performans göstergeleri.

\begin{tabular}{|c|c|c|c|c|c|c|c|c|c|c|}
\hline \multirow{2}{*}{$\begin{array}{l}\text { Toprak } \\
\text { özelliği }\end{array}$} & \multirow{2}{*}{$\begin{array}{l}\text { Meşcere } \\
\text { tipi }\end{array}$} & \multicolumn{2}{|c|}{ Aritmetik ortalama } & \multicolumn{2}{|c|}{ Standart sapma } & \multicolumn{2}{|c|}{ Varyasyon katsayısı } & \multicolumn{3}{|c|}{ Krigleme başarı ölçütleri } \\
\hline & & Ölçülen & $\begin{array}{l}\text { Tahmin } \\
\text { edilen }\end{array}$ & Ölçülen & $\begin{array}{l}\text { Tahmin } \\
\text { edilen }\end{array}$ & Ölçülen & $\begin{array}{l}\text { Tahmin } \\
\text { edilen }\end{array}$ & $\mathbf{r}$ & RMAE & RRMSE \\
\hline \multirow{4}{*}{ HA } & 1 & 1,14 & 1,14 & 0,21 & 0,0028 & 18,42 & 0,24 & 0,23 & 30,86 & 48,56 \\
\hline & 2 & 1,34 & 1,33 & 0,19 & 0,0034 & 14,18 & 0,26 & 0,08 & 3,92 & 19,42 \\
\hline & 3 & 1,04 & 1,03 & 0,17 & 0,0019 & 16,35 & 0,19 & 0,25 & 65,33 & 67,35 \\
\hline & 4 & 1,18 & 1,18 & 0,17 & 0,0021 & 14,41 & 0,18 & 0,09 & 19,31 & 40,43 \\
\hline \multirow[t]{4}{*}{ pH } & 1 & 5,48 & 5,45 & 0,58 & 0,1893 & 10,58 & 3,47 & 0,10 & 8,31 & 68,64 \\
\hline & 2 & 5,36 & 5,34 & 0,57 & 0,0290 & 10,63 & 0,54 & 0,10 & 7,84 & 63,61 \\
\hline & 3 & 5,52 & 5,53 & 0,54 & 0,0439 & 9,78 & 1,79 & 0,18 & 7,73 & 63,69 \\
\hline & 4 & 5,40 & 5,94 & 0,50 & 0,0207 & 9,26 & 0,35 & 0,02 & 7,03 & 58,55 \\
\hline \multirow[t]{4}{*}{ EC } & 1 & 163,36 & 164,18 & 69,70 & 219,7783 & 42,67 & 133,86 & 0,05 & 5487,06 & 4593805,3 \\
\hline & 2 & 108,49 & 108,98 & 59,14 & 252,4711 & 54,51 & 231,67 & 0,19 & 37,91 & 5932,09 \\
\hline & 3 & 181,40 & 182,34 & 70,83 & 344,1896 & 39,05 & 188,76 & 0,10 & 30,68 & 7084,18 \\
\hline & 4 & 146,04 & 146,67 & 63,24 & 315,4562 & 43,30 & 215,08 & 0,16 & 33,91 & 6274,40 \\
\hline \multirow{4}{*}{$\begin{array}{l}\text { Kum } \\
\text { (\%) }\end{array}$} & 1 & 43,34 & 43,01 & 7,12 & 12,1629 & 16,43 & 28,28 & 0,26 & 12,09 & 674,94 \\
\hline & 2 & 38,71 & 38,53 & 6,32 & 14,2664 & 16,33 & 37,03 & 0,46 & 10,94 & 57,21 \\
\hline & 3 & 47,80 & 47,45 & 6,35 & 10,5068 & 13,28 & 22,14 & 0,32 & 6,34 & 609,67 \\
\hline & 4 & 45,30 & 45,37 & 6,95 & 6,0524 & 15,34 & 13,34 & 0,32 & 11,86 & 645,20 \\
\hline \multirow[t]{4}{*}{ Kil (\%) } & 1 & 36,46 & 36,85 & 5,19 & 4,2482 & 14,23 & 11,53 & 0,25 & 10,94 & 513,54 \\
\hline & 2 & 39,50 & 39,49 & 5,60 & 2,8345 & 14,88 & 7,18 & 0,03 & 10,62 & 615,96 \\
\hline & 3 & 33,38 & 33,44 & 4,79 & 3,3126 & 14,35 & 9,91 & 0,08 & 12,30 & 511,10 \\
\hline & 4 & 35,15 & 35,26 & 4,76 & 3,1021 & 13,54 & 8,80 & 0,27 & 10,95 & 526,73 \\
\hline \multirow[t]{4}{*}{ Silt (\%) } & 1 & 20,18 & 20,12 & 4,45 & 2,9572 & 22,05 & 14,70 & 0,03 & $\begin{array}{ll}17,39 \\
\end{array}$ & 453,03 \\
\hline & 2 & 21,77 & 21,58 & 6,02 & 4,9015 & 27,65 & 22,71 & 0,18 & 18,77 & 641,34 \\
\hline & 3 & 18,82 & 18,86 & 4,06 & 4,6140 & 21,57 & 24,46 & 0,44 & 15,35 & 359,12 \\
\hline & 4 & 19,54 & 19,20 & 4,82 & 2,8383 & 24,67 & 14,78 & 0,02 & 18,20 & 479,88 \\
\hline \multirow{4}{*}{$\begin{array}{l}\mathrm{CaCO}_{3} \\
(\%)\end{array}$} & 1 & 2,17 & 2,16 & 0,43 & 0,0094 & 19,82 & 0,44 & 0,03 & 4325,8 & 47579,2 \\
\hline & 2 & 2,15 & 2,15 & 0,29 & 0,0019 & 13,49 & 0,55 & 0,06 & 11,94 & 49,52 \\
\hline & 3 & 2,39 & 2,37 & 0,39 & 0,0248 & 16,32 & 1,05 & 0,37 & 6,36 & 36,34 \\
\hline & 4 & 2,36 & 2,35 & 0,39 & 0,0218 & 16,53 & 0,93 & 0,23 & 4,47 & 41,01 \\
\hline \multirow[t]{4}{*}{ OM } & 1 & 9,68 & 9,51 & 2,0 & 0,5958 & 22,73 & 6,26 & 0,16 & 18,99 & 218,50 \\
\hline & 2 & 6,48 & 6,53 & 1,94 & 0,4266 & 29,94 & 6,53 & 0,05 & 26,55 & 211,78 \\
\hline & 3 & 10,90 & 10,98 & 2,74 & 1,9472 & 25,14 & 17,74 & 0,24 & 18,29 & 255,77 \\
\hline & 4 & 8,86 & 8,81 & 2,53 & 0,8306 & 28,56 & 9,43 & 0,18 & 24,80 & 256,45 \\
\hline \multirow[t]{4}{*}{$\mathbf{P}$} & 1 & 0,15 & 0,14 & 0,08 & 0,0009 & 53,33 & 0,67 & 0,23 & 30,86 & 48,56 \\
\hline & 2 & 0,10 & 0,10 & 0,07 & 0,0004 & 70,00 & 0,47 & 0,18 & 3,92 & 19,42 \\
\hline & 3 & 0,16 & 0,17 & 0,11 & 0,0046 & 68,75 & 2,73 & 0,25 & 65,33 & 67,35 \\
\hline & 4 & 0,13 & 0,13 & 0,08 & 0,0010 & 61,54 & 0,78 & 0,42 & 19,31 & 40,43 \\
\hline
\end{tabular}


Tablo 3. Devam ediyor.

\begin{tabular}{|c|c|c|c|c|c|c|c|c|c|c|}
\hline \multirow{2}{*}{$\begin{array}{l}\text { Toprak } \\
\text { özelliği }\end{array}$} & \multirow{2}{*}{$\begin{array}{l}\text { Meşcere } \\
\text { tipi }\end{array}$} & \multicolumn{2}{|c|}{ Aritmetik ortalama } & \multicolumn{2}{|c|}{ Standart sapma } & \multicolumn{2}{|c|}{ Varyasyon katsayısı } & \multicolumn{3}{|c|}{ Krigleme başarı ölçütleri } \\
\hline & & Ölçülen & $\begin{array}{l}\text { Tahmin } \\
\text { edilen }\end{array}$ & Ölçülen & $\begin{array}{l}\text { Tahmin } \\
\text { edilen }\end{array}$ & Ölçülen & $\begin{array}{l}\text { Tahmin } \\
\text { edilen }\end{array}$ & $\mathbf{r}$ & RMAE & RRMSE \\
\hline \multirow[t]{4}{*}{ TK } & 1 & 28,80 & 28,43 & 7,27 & 4,8564 & 25,24 & 17,08 & 0,31 & 19,71 & 673,73 \\
\hline & 2 & 25,88 & 25,52 & 6,14 & 3,6524 & 23,72 & 14,31 & 0,07 & 17,76 & 579,13 \\
\hline & 3 & 29,41 & 29,96 & 8,78 & 11,9049 & 29,85 & 39,73 & 0,27 & 23,53 & 855,33 \\
\hline & 4 & 26,12 & 26,39 & 6,76 & 4,5399 & 25,88 & 17,20 & 0,11 & 20,68 & 722,44 \\
\hline \multirow[t]{4}{*}{ SN } & 1 & 15,75 & 15,60 & 4,48 & 3,0097 & 28,44 & 19,30 & 0,03 & 21,45 & 419,21 \\
\hline & 2 & 13,78 & 13,75 & 4,05 & 1,6468 & 29,39 & 11,98 & 0,04 & 22,20 & 375,21 \\
\hline & 3 & 17,76 & 18,09 & 5,07 & 2,8712 & 28,55 & 15,87 & 0,04 & 23,11 & 510,45 \\
\hline & 4 & 15,22 & 15,50 & 4,96 & 2,2058 & 32,59 & 14,23 & 0,01 & 24,91 & 508,01 \\
\hline \multirow[t]{4}{*}{ YSİ } & 1 & 13,04 & 12,41 & 5,77 & 5,2391 & 44,25 & 44,22 & 0,39 & 35,38 & 530,04 \\
\hline & 2 & 12,10 & 11,38 & 5,31 & 3,5554 & 43,88 & 31,25 & 0,30 & 33,87 & 492,19 \\
\hline & 3 & 11,65 & 11,90 & 6,68 & 7,0554 & 57,34 & 59,31 & 0,15 & 44,69 & 671,60 \\
\hline & 4 & 10,90 & 10,84 & 5,07 & 0,9070 & 46,51 & 8,37 & 0,76 & 4672,76 & 145033,10 \\
\hline
\end{tabular}

HA: Hacim ağırlı̆̆ $\left(\mathrm{g} / \mathrm{cm}^{-3}\right)$, EC: elektriksel iletkenlik ( $\left.\mu \mathrm{s} / \mathrm{cm}\right)$ OM: Organik madde (\%), P: Fosfor ( $\left.\mathrm{cmol} \mathrm{kg}^{-1}\right)$, TK: Tarla kapasitesi (\%), SN: Solma noktası (\%), YSİ: Yarayışlı su içeriği (\%), VK: Varyasyon katsayısı, 1: Karışık meşcere (0-15 cm), 2: Karışık meşcere (15-30 $\mathrm{cm}), 3$ : Saf meşcere $(0-15 \mathrm{~cm}), 4$ : Saf meşcere $(15-30 \mathrm{~cm})$.

Tablo 3'de RMAE değeri \%10 ve altında olan toprak özellikleri için bayağı (ordinary) krigleme ile elde edilen haritalar Şekil 2'de toplu olarak verilmiştir. Şekil 2 incelendiğinde, $\mathrm{pH}$ değerlerinin her dört durumda da meşcerelerin ortalarında yüksek değerler aldığ 1 gözlenmektedir. Aynı durum, saf meşcerede 0-15 cm derinlikte kum için de geçerlidir. Kireç ise çalışma alanın batı kenarında daha yüksek değerler almıştır.

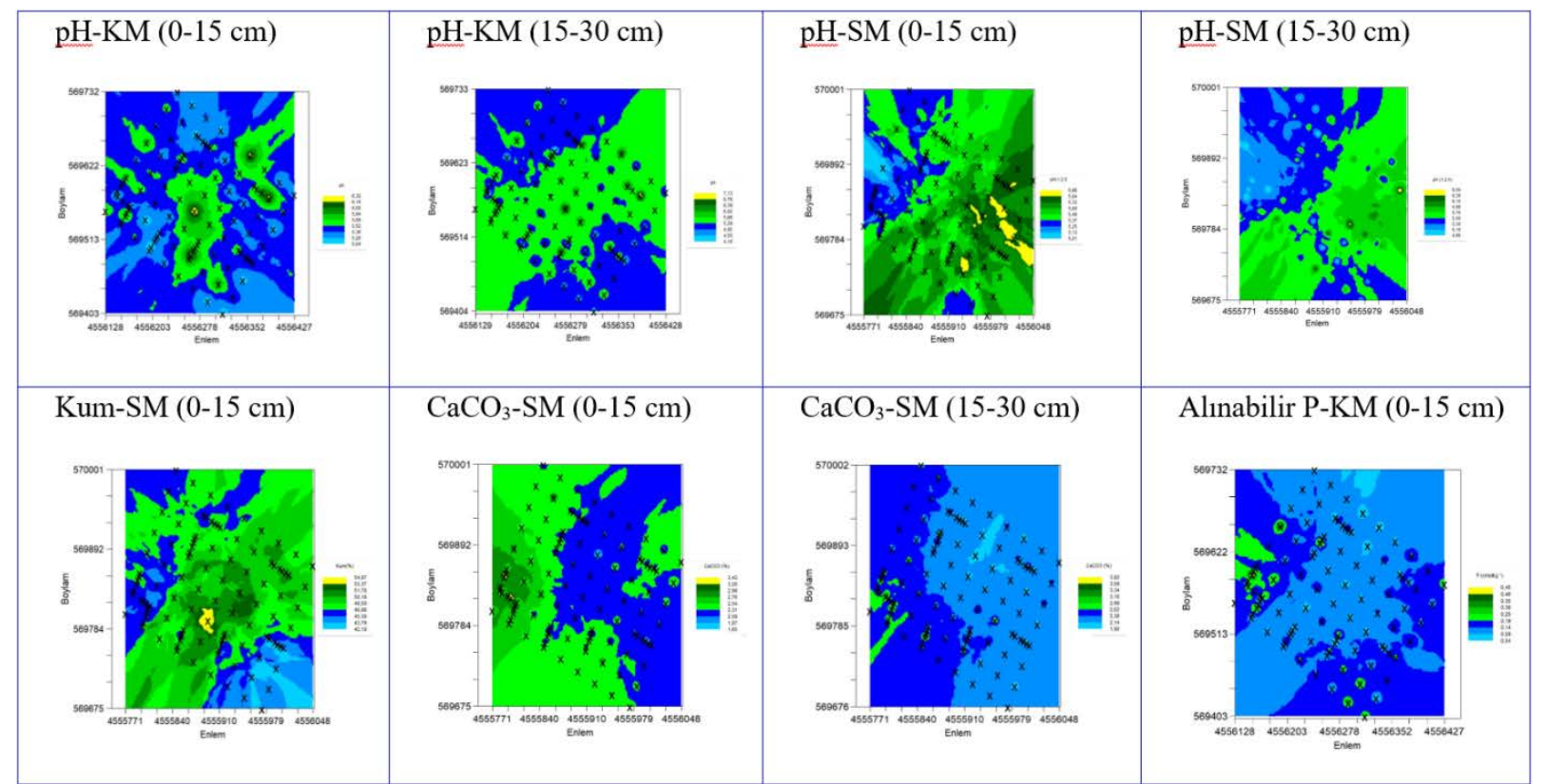

Şekil 2. Çalışma alanında bazı toprak özelliklerinin karışık (KM) ve saf meşcerede (SM) 0-15 ve 15-30 cm derinliklerde uzaysal dağılım deseni.

\section{Sonuç ve Öneriler}

Kastamonu ili Ilgaz doğal orman alanı içinde yaklaşık 5 er ha genişliğinde, saf göknar ve saf göknar - sarıçam karışık meşcerede 0-15 ve 15-30 cm derinliklerdeki toprakların uzaysal değişkenliklerinin gerek meşcere tipi bakımından gerek toprak derinliği bakımında farklı olduğu belirlenmiştir. Uzaysal bağımlılık 0-15 cm'de, 15-30 cm'de olduğundan daha düşük olup, bu farklılığın mikro topografya ve orman altı bitki örtüsü etkileşiminin 0-15 cm’de daha etkili olmasından kaynaklandığı düşünülmektedir. Ancak toprak derinliği ile karşılaştırıldığında, meşcere tipiden kaynaklanan farkın daha düşük olduğu görülmektedir. Toprak özelliklerinin uzaysal değişkenliği 
arasında meşcere tipine bağlı olarak sistematik bir farkın daha düşük olması, 0-15 cm için topografya ve özellikle de mikro topografyadaki farklılığın meşcere tipinden kaynaklanan değişkenliği baskıladığını düşündürmektedir. Arazi çalışması esnasında, toprağın orman ağaçları altında ve ağaçlar arasında sık sık değiştiği, ayrıca çalışma alanının mikro topoğrafyası ve orman altı bitki örtüsünün çok sık değiştiği gözlenmiştir. Çalışma alanının eğimli olması ve taşınma birikme olaylarının sürekliliği dikkate alındığında, 15-30 cm derinlikte de, 0-15 cm deki kadar olmasa bile, yine topografyanın etkisinin bitki örtüsüne (meçcere tipi) göre daha baskın olduğu söylenebilir. Uzaysal enterpolasyonda istenen başarının elde edilememiş olması, toprakların kısa mesafelerde aşırı değişken olması ve mevcut örnekleme deseni ve sıklığı ile bu değişkenliğin yakalanamamasına bağlanmıştır. İleride yapılacak benzer çalışmalarda bu hususa özellikle dikkat edilmelidir.

\section{Teşekkür}

Bu çalışmaya verilen destek için Çankırı Karatekin Üniversitesi Bilimsel Araştırmalar Birimine (ÇAKÜ-BAP) teşekkür ederiz. Proje No: OF061218D06

\section{Kaynaklar}

1. Akbaş, F., (2004). Entisol Ordosuna Ait Bir Arazide Bazı Toprak Özelliklerinin Değişiminin Geleneksel ve Jeoistatistiksel Yöntemlerle Belirlenmesi. Doktora Tezi, Gaziosmanpaşa Üniversitesi, Fen Bilimleri Enstitüsü, Toprak Anabilim Dalı, Tokat, 52-78 s.

2. Başaran, M., Özcan M. U., Erpul G., Çanga, M. (2005). Çankırı-İndağı Karaçam (Pinus nigra Arnold.) plantasyon alanında mineral üst toprağın organik madde kapsamı ve bazı özelliklerinin konumsal değişimleri. Gazi Üniversitesi Orman Fakültesi Dergisi. Kastamonu, Cilt:5 No:2 Kasım 2005.

3. Blake, G. R., Hartge, K. H. (1986). Methods of soil analysis. Bulk Density, Part 1. 2nd Ed. Agronomy 9. ASA and SSSA, 363-375.

4. Boruvka, L., Mladkova, L., Penizek, V., Drabek, O., Vasat, R. (2007). Forest soil acidification assesment using principal component analysis and geostatistics. Geoderma 2007(140), 374-382.

5. Cambardella, C. A., Moorman, T. B., Novak, J. M., Parkin, T. B., Karlen, D. L., Turco, R. F., Konopka, A. E. (1994). Field-scale variability of central Iowa soils. Soil Sci. Soc. Am. J. 58, 15011511. https://doi.org/10.2136/sssaj1994.03615995005800050033x.

6. Camberdella, C. A., and Karlen I. D. (1999). Spatial analysis of soil fertility parameters. Precision Agriculture, 1, 5-14.

7. Cassel, D. K., Nielsen, D. R. (1986). Methods of soil analiysis. Part 1, Physical and Mineralogical Methods-Agronomy Monoraph No:9 American Society Of Agronomy-Soil Science Society of America, Madison, USA.

8. Castrignano, A. L., Giugliarini, R., Risaliti and Martinelli, N. (2000). Stuy of sparial relationships among some soil physico- chemical properties of a field in central İtaly using multi variate geotattistics. Geoderma 97, 39-60.

9. Charles, T., Garten, Jr. (2002). Soil carbon storage beneath recently established tree plantations in Tennessee and South Colorina, USA, Biomas and Bioenergy, 23, 93-102.

10. Çetin, M., Tütüncü, K. (1998). Doğu akdeniz bölgesinde aylık yağışların yersel değişimlerinin jeostatistik yöntemle incelenmesi. Turkish Journal of Engineering and Environmental Science, 22, 279288.

11. Erşahin, S., (1999). Alivuyal bir tarlada bazı fiziksel ve kimyasal toprak özelliklerinin uzaysal (spatial) değişkenliğinin belirlenmesi. S.Ü. Ziraat Fakültesi Dergisi. 13(19), 34-41.

12. Ersahin, S., Brohi, A. (2006). Spatial variation of soil water content in topsoil and subsoil of a Typic Ustifluvent. Agric. water Manag. 83, 79-86. https://doi.org/10.1016/j.agwat.2005.09.002.

13. Ersahin, S., Aşkın, T., Tarakçığlu, C., Özenç, D. B., Korkmaz, K., Kutlu, T., Sünal, S., Bilgili, B. C. (2017). Spatial variation in the solute transport attributes of adjacent Typic Haplusteps, Mollic Ustifluvents, and Lithic Ustipsamments. Geoderma 289, 107-116. https://doi.org/org/10.1016/j.geoderma.2016.11.035.

14. Gallardo, A., (2003). Spatial variability of soil properties in a floodplain forest in northwest spain. Ecosystems 2003(6), 564-576.

15. Gallardo, A., Parama, R. (2007). Spatial variability of soil elements in two plant communities of NW Spain. Geoderma, 139(1-2), 199-208.

16. Gee, G. W., Bauder, J. V. (1986). Particle-size Analysis. Methods of soil analysis, Part1, Physical and mineralogical methods. Second Edition, Agronomy Monograph 9, American Society of Agronomy, Madison, In A.L. Page (ed.). WI. P. 383 - 411.

17. Geypens, M., Vanongeval, L., Vogels, N., Meykens, J. (1999). Spatial variability of agricultural soil fertility parameters in a gleyic podzol of belgium. Precision Acriculture 1, 319-326. 
18. Gregory, J. H, Dukes, M. D, Jones P. H, Miller, G. L. (2006). Effect of urban soil compaction on infiltration rate. Journal of Soil Water Conservation 61(3), 117-124.

19. Gül, E. (2015). Yarı-Kurak Alanlarda Çölleşme Risk Haritasının Oluşturulması: Sarıkaya Örneği. Doktora Tezi, Karatekin Üniversitesi Fen Bilimleri Enstitüsü, Orman Mühendisliği Anabilim Dalı, Çankırı, 108-118 s.

20. Gül, E., Erşahin, S. (2019). Evaluating the desertification vulnerability of a semiarid landscape under different land uses with the environmental sensitivity index. Land Degradation \& Development 30, 811-823.

21. Isaaks, H., Srivastava, R. (1989). An introduction to Applied Geostatistics. Oxford University Press, New York. 210-255 pages.

22. Janzen, H. H. (1993). Soluble salts in soil sampling and methods of analysis. Carter M.R. (ed) Canadian Society of Soil Science, CRC Pres Inc. Boca Raton, Florida. USA.

23. Jennifer, M., Turner, G. M., Person, M. G., Dixon, P. (2005). Effects of past land use on spatial heterogeneity of soil nutrients in southern Appalachian forests. Ecological Monographs 75(2), 215-230.

24. Journel, A., Huijbregts, Ch. J. (1978). Mining geostatstics. Academic press. $600 \mathrm{~s}$.

25. Kacar, B., Kovancı, İ. (1982). Bitki, toprak ve gübrelerde kimyasal fosfor analizleri ve değerlendirilmesi. Ege Üniversitesi Ziraat Fakültesi Yayınları, No: 354.

26. Kacar, B. (1996). Bitki ve Toprak Analizleri. 3. Ankara Üniversitesi Ziraat Fakültesi Eğitim, Araştırma ve Geliştirme Vakfı Yayınları, No: 3.

27. Li, J., Heap, A. D. (2011). A review of comparative studies of spatial interpolation methods in environmental sciences: Performance and impact factors. Ecological Informatics, 6(3-4), 228-241. https://doi.org/10.1016/j.ecoinf.2010.12.003.

28. Mualla, D. J., McBratney, A. B. (2000). Soil Spatial Variability, A-321-A351, İn: handbook of soil science, malcom e. Summer (ed. İn chief) CRS press, 321-352 pages.

29. Needelman, B. A., Guburek, W. J., Sharpley A. N., Petersen, G. W. (2001). Environmental Management of Soil Phosphorus. Soil Science Society of America Journal, 65(5), 1516-1522.

30. Nelson, D. W., Sommers, L. E. (1982). Total Carbon, Organic Carbon, and Organic Matter. In: Page, A.L. (ed.) Methods of Soil Analysis. Part 2, 2nd ed. Agron. Monogr. 9. ASA. Madison, WI, 539-579.

31. Nielsen, D. R., Biggar, J. W., Erh, T. H. (1973). Spatial variability of field measured soil-water properties. Hilgarda 42(7), 214-259.

32. Ongun, R., (2008). Toprakların Bazı Fiziksel ve Kimyasal Özelliklerinin Jeoistatistiksel Yöntemlerle Uzaysal Değişkenliğinin Saptanması. Doktora Tezi, Ege Üniversitesi Fen Bilimleri Enstitüsü, Toprak Anabilim Dalı, İzmir, 70-117 s.

33. Ott, R. L. (1993). An introduction to statistical methods and data analysis. Fourt Edition, Duxbury Press, Belmont, California.

34. Ovalles, F. A., Collings, M. A. (1988). Soil- lands cape relationships and soil variability in north central florida. Soil Science Society of America Journal 50, 401-408.

35. Payn, W. T., Hill, B. R., Höck, K. B., Skinner, F. M., Thorn, J. A., Rijkse. C. W. (1999). Potantial foor the use of gis and spatial analysis thecniques as tolls for monitoring chances in forest productivity and nutrition a new zealland example. 122, 187-196.

36. Sağlam, M. (2008). Gökhöyük Tarım İşletmesinde Yaygın Toprak Serilerinde Bazı Kalite Göstergelerinin Uzaysal Değişkenliğinin Jeoistatistiksel Yöntemlerle Belirlenmesi. Doktora Tezi, Ankara Üniversitesi Fen Bilimleri Enstitüsü, Toprak Anabilim Dalı, Ankara, 32-79 s.

37. Sun, B., Zhou, S., Zho, Q. (2003). Evaluation of spatial and temporal changes of soil quality based on geostatistical analysis in the hill region of sabtropical china. 115, 85-99.

38. Trangmar, B. B., Yost, R. S., Uehara, G. (1985). Aplication of geostatistic to spatal studies of soil properties. Advances in Argon (38), 45-94.

39. Warrick, A., Nielsen W. (1980). Warrick, A. W., \& Nielsen, D. R. (1980). Spatial variability of soil physical properties in the field. In D. Hillel (Ed.), Applications of soil physics (pp. 319-344). New York: Academic Press.

40. Webster, R. (2001). Statistics to support soil research and their presentation. Eur. J. Soil Sci. 52, 330340. https://doi.org/10.1046/j.1365-2389.2001.00383.x

41. Webster, R. (2008). Sil science and geostatistics. 1-11. Soil geopraphy and geostatistics-european commission, krasilnikov, P, Carre, F and Montanarella, L. Eds), european commission, joint research centre, institute for environmental and sustainability.

42. Webster, R., Oliver, M. A. (2001). Geostatistics for environmental scientists (Statistics in practive).

43. Webster, R., and Oliver, M. A. (2007). Geostatistics for environmental scientists. John Wiley\&Sons. European Journal Of Soil Science, June 2001(52), 331-340.

44. Wu, J., Norvell, W. A., Hopkings, D. G., Welch, R. M. (2002). Spatial variability of grain cadmium and soil characteristics in a durum wheat field. Soil Science Society of America Journal 66(1), 268-275. 